\title{
A montagem perversa positiva na revista Nin
}

\section{Perverse positive montage in Nin Maganize}

José Miguel Arias Neto

Universidade Estadual de Londrina (UEL)

<jneto@uel.br>

Muriel Emídio Pessoa do Amaral

Universidade Estadual Paulista (Unesp/Bauru) <murielamaral@yahoo.com.br>

\section{RESUMO}

\begin{abstract}
A proposta desse artigo é de compreender como o conceito de montagem perversa pode contribuir para oferecer um leque de representações fora do esquadro de conceitos cristalizados. Para isso, esse texto se apropria do discurso e das imagens da revista Nin e aborda como a publicação apresenta elementos perversos para a redefinição de identidades, sexualidade, gênero e desejo, não se limitando apenas em apresentar signos engessados sobre esses assuntos, oferecendo uma condição de montagem perversa positiva.
\end{abstract}

Palavras-chave: Revista Nin. Montagem. Perversão.

\begin{abstract}
The proposal of this article is to understand how the concept of perverse montage can contribute to offer a range of representations outside the square of crystallized concepts. To that end, this text appropriates the discourse and images of Nin magazine to address how the publication presents perverse elements for the redefinition of identities, sexuality, gender and desire, not only to present embedded signs on these subjects, offering a condition of positive perverse montage.
\end{abstract}

Keywords: Revista Nin. Montage. Perversion.

\section{INTRODUÇÃO}

Não raro as significações e sentido de perversão estão associados a percepções que remetem a desprezo, agressividade, repugnância, àquilo que pode ser ofensivo e repulsivo. Essas noções ganham proporções mais ofensivas quando o assunto é sexualidade. De fato, existe a possibilidade de as perversões serem enquadradas como algo associado ao horror. Em contrapartida, elas podem ser compreendidas como alternativas a sistemas opressores e controlados que forjam subjetividades, corpose, principalmente, valores éticose morais. Não existiria a subversão se não houvesse constituições que prezam pela normatização e disciplina. Essas considerações são importantes para verificar que discursos e práticas perversas podem ser interessantes e necessários para o sistema social, uma vez que se tornam manifestações políticas porque oferecem 
uma gama de possibilidades de representações e soluções fora dos esquadros previamente estipulados. Essa alternativa será chamada de montagens perversas positivas, pois trarão alguns pontos relevantes para o espaço social, seja por uma nova forma de representação, seja pelo enfrentamento de ações convencionais. Com esses meandros é constituída a capacidade editorial da revista Nin - naked for no reason, ou simplesmente Nin, o objeto de estudo desse texto; uma descompressão dos ditames sobre sexualidade daquilo que é socialmente aceito.

O nome da revista é uma alusão à escritora e poetisa francesa Anaïs Nin, reconhecida internacionalmente pela produção literária erótica. Nin é carioca e nasceu da iniciativa de Alice Galeffi e Letícia Gicovate, com o propósito de organizar uma revista erótica que evidenciasse várias representações. Apenas isso. Sua linha editorial não clama por um segmento específico de público delimitado pelo sexo, orientação sexual ou identidade de gênero. Está em jogo apenas a fluição do desejo. A revista Nin opera nesse sentido e traz, sem qualquer pudor, imagens de homens, mulheres e transexuais nas mais diversas condições: gordas, baixas, altas, peludas, sem pelos, carecas, evidenciando as genitálias, axilas, pelos pubianos e menstruação em cenas do cotidiano. A publicação também subverte a ordem de produção convencional de conteúdo, mesclando em suas páginas desenhos, ilustrações, ensaios fotográficos, artigos com tendência acadêmica; também não há índice, editorias fixas, muito pouca coisa que possa se assemelhar a um periódico comum. Há traços perversos na necessidade de reconfiguração dos conteúdos na revista.

A perversão de Nin se aloja na montagem que é realizada para representação das sexualidades, gêneros e identidades. Por montagem, é importante considerarmos seu uso a partir da psicanálise que, em suma, é a elaboração de leis próprias que o indivíduo organiza para não ser submetido ao processo decastração(Sibony, 1987; Szpacenkopf,2003)e, assim, gozar. Enquanto uma produção discursiva, a montagem será compreendida como sendo uma construção poética particularizada e que objetiva a oferta de outra organização. Na mesma medida, a montagem pode se articular e promover enfrentamentos e deboches das representações que se encontram marmorizadas no bojo social, podendo ser interpretadas como desaforo e inquietude pela necessidade de reconfigurações; "a frivolidade também é uma perversão", como consta no filme Youth, do diretor Paolo Sorrentino.

É importante notar que, a despeito das perversões, principalmente as de cunho sexual, serem representadas como aquilo que é abjeto, nesse texto haverá a intenção de promovê-las como ações importantes no espaço social para a ressignificação de paradigmas e, assim, torná-las positivas. A publicação 
enfatiza a estética queer, aquilo que é estranho, esquisito, mas necessário para movimentos políticos em defesa da diversidade como modo de questionamento das estruturas de poder (Miskolci, 2009). A intenção queer não é de se limitar a códigos fechados de representação, mas apresentar fluidez e subversão às estruturas esquematizadas.

Com essas notas, o texto pretende apresentar noções significativas da psicanálise sobre as perversões (Freud, 1996, 2006; Ferraz, 2000) enquanto uma condição estruturante do psiquismo humano (Lanteri-Laura, 1994; Dor, 1991). Com esse aparato construído, a pesquisa busca verificar como as imagens e os textos pretendem quebrar paradigmas e noções de gênero e identidade, segundo uma proposta pós-estruturalista (Preciado, 2014; Butler, 2003; Foucault, 1988). Enquanto representações sociais, as perversões serão vistas sob o ponto de vista de Szpacenkopf (2003), que analisa como a objetificação e a instrumentalização do outro podem ser práticas sociais perversas, muitas vezes naturalizadas. Ainda no âmbito social, Roudinesco (2003), além de apresentar um panorama histórico das perversões, evidencia, assim como Dufor (2013), como as perversões podem ser compreendidas e reconhecidas como propostas positivas à sociedade.

\section{AS FACES DAS PERVERSÕES}

A epistemologia adotada por esse texto não pretende limitar as perversões a comportamentos nocivos ou agressivos à sociedade ou que firam a ordem moral de tal forma que possam trazer máculas à coletividade. Para esse texto, mesmo trazendo um leque de aplicações sobre o tema, a perversão baseia-se na intenção de promover ações e representações libertárias aos conceitos e significações previamente estabelecidas por códigos morais e culturais. Pensar a perversão enquanto formas discursivas de conhecimento é atentar que essas práticas fogem da curva de convenções e signos limitadores de representações. Por isso, o reconhecimento de algumas perversões como propostas libertárias de significação.

Enquanto manifestações sociais, as perversões reconhecem o outro como um instrumento para o prazer próprio, como aponta Szpacenkopf (2003). O sujeito não reconhece, tão pouco valoriza a condição do outro no espaço social, o que justifica e explica humilhações, extermínios e desmerecimentos. Por outro lado, as perversões podem ser interessantes para o espaço social quando as ações promovem enfrentamentos em nome de possibilidades libertárias. A partir dessa proposta epistemológica, as edições da revista Nin podem ser consideradas como sendo perversas, pois desafiam e colocam em 
xeque as representações marmorizantes das sexualidades, das identidades, dos gêneros, dos desejos e, porque não, das libidos e fetiches. Além disso, tornase frutífero também analisar como os conceitos e os modos de representação das perversões se alteraram ao longo dos anos, sendo compreendidos como sintomas de códigos morais que estão em compasso com as dinâmicas culturais e sociais.

As primeiras aparições do termo perversão, alega Lanteri-Laura (1994), são de 1444 , no sentido de apontar comportamentos que orbitavam fora de uma ordem de convencionalidade; era uma alusão à palavra em latim perversione, que se refere a reverter ou retornar, àquilo que oferece uma tendência em ser uma qualidade diferente à norma. Foi no século XIX, com o advento do desenvolvimento do discurso científico e jurídico, que foram estabelecidas divisões sociais entre normalidades e patologias. Nesse contexto, as perversões passaram a receber denotações de degradação fora de uma questão orgânica biológica, mas também moral.

Ferraz (2000) aponta outras nuances das perversões para além do campo científico como a aproximação das perversões aos valores morais, como uma proposta de distinguir os sujeitos entre aqueles que teriam comportamentos adequados ou não para o convívio em sociedade. Além disso, houve também a desinência das perversões para o campo das sexualidades, o que evidenciou as perversões mais atreladas ao campo das sexualidades. Como sintoma dessas referências, Richard Krafft-Ebing escreveu, em 1886, a obra Psicopatia sexual [Psychopathia Sexualis, título original], em que apresenta e cataloga casos e manifestações considerados patológicos, enquanto práticas das sexualidades, classificando quais comportamentos seriam adequados ou aberrantes, segundo os valores morais e científicos, como homossexualidade, sadismo e masoquismo, por exemplo. Krafft-Ebing, de fato, apresentou atitudes e comportamentos até hoje considerados repulsivos, como a necrofilia. Todavia, sua lista de psicopatias também contemplava comportamentos fora da ordem heteronormativa, como os desejos e práticas homoeróticas.

Para Foucault (1988), existe uma relação de poder a ser considerada sobre as doutrinas propagadas no século XIX, principalmente as de cunho científico e médico. Esses discursos legitimam seus conhecimentos como referências de verdade porque exerceram relações que subsidiam bases para hierarquizar, investigar, distinguir e refutar os comportamentos e sexualidades que não estivessem a par dos códigos considerados como adequados à normatização social. Esses discursos também promoveram a heterossexualidade compulsória, a constituição tradicional familiar e o combate às sexualidades periféricas, aquelas que incidem fora da heteronormatividade, que não estão a par das forças 
reprodutivas, tanto biológicas, como econômicas. É importante frisar, também, que não é apenas a desinência do aspecto científico que foi apoio para moldes de subjetividades e exercício de poder, mas também os códigos familiares, os discursos religiosos e pedagógicos, que reprimiram e autorizaram modos de compreender desejos, sexualidades e poder, e, obviamente, ofereceram condições para vigilância, acompanhamento e estratificação das sexualidades e sujeitos.

Nessas passagens, Foucault considera que tais referências seriam carregadas de altos valores perversos porque anulam subjetividades, domesticam os corpos, desqualificam desejos e impõem uma ordem unificada para lidar com a sexualidade:

\footnotetext{
A sociedade "burguesa" do século XIX e sem dúvida a nossa, ainda, é uma sociedade de perversão explosiva e fragmentada. Isso, não de maneira hipócrita, pois nada foi mais manifesto e prolixo, nem mais abertamente assumido pelos discursos e instituições. Não porque, ao querer erguer uma barreira demasiado rigorosa ou geral contra a sexualidade tivesse, a contragosto, possibilitado toda uma germinação perversa e uma séria patologia do instinto sexual. Tratase, antes de mais nada, do tipo de poder que exerceu sobre o corpo e o sexo, um poder que, justamente, não tem a forma da lei nem os efeitos da interdição: ao contrário, que procede mediante a redução das sexualidades singulares (Foucault, 1988, p. 55).
}

Ainda na esteira do pensamento foucaultiano, a formação das subjetividades, pela circulação desses discursos, promove perversões também pela implantação de hierarquizações e a promoção de isolamento entre os indivíduos que não estariam aptos e moralmente capacitados para conviver em sociedade, cabendo a esses indivíduos a readequação comportamental e o distanciamento moral.

Entretanto, foi também no final do século XIX que a perversão foi observada sob outra ótica. A relação existente entre desejo e fantasia foi um marco primordial para resssignificar como seriam estruturadas as perversões, bem como outros comportamentos humanos. Entram em cena os preceitos da psicanálise para compreender que a perversão não se trata apenas da incidência de atitudes reprováveis ou aberrantes, no meio social, que prejudicam a convivência em toda sua coletividade e oferecem condições para o fomento para o mal. No entendimento de Freud (2016) que, posteriormente, foi aprimorado por Lacan, a estrutura do psiquismo é estabelecida pela relação de fantasia que se desenvolve na criança pelo desejo ao seu primeiro objeto de 
gozo, a mãe, tendo a interferência do falo para a quebra do gozo, esse edificado no envolvimento entre a criança e a mãe. Por estrutura, essa pesquisa se apoia no entendimento de Dor (1991) de que há uma relação de afeto e proximidade entre as partes envolvidas para a construção estrutural. Assim, uma estrutura é um conjunto de elementos guiado por uma série de leis que compõe a dinâmica dessas relações entre tais elementos; leva-se em conta que muitos desses acordos formados pelas leis conjugam uma estrutura que é orquestrada inconscientemente.

A intenção desse texto não é de se debruçar sobre as demais estruturas neuroses (histeria e obsessão) e psicoses ${ }^{1}$-, ficaremos retidos apenas à estrutura perversa, que se edifica sob o aspecto de renegar a castração. Como uma das saídas para o complexo de Édipo², a perversão está atrelada à renegação. Essa relação foi teorizada por Freud (1996) como sendo Verleugnung (termo alemão para designar renegação) em que o sujeito percebe que a mãe, objeto de gozo, não é dotada de falo. Essa situação de afeto desenvolve, no sujeito, inconscientemente, o movimento de reconhecer no pai uma figura que castrou a mãe e, possivelmente, o castrará também. Além do mais, o sujeito visualiza, pela intervenção fálica do pai, o rompimento com o objeto de gozo que, no caso, é a própria mãe. Operando dentro dessa perspectiva, o sujeito mantém mecanismos para manter o gozo, elaborando leis próprias que possam renegar indícios de castração.

Por esse aspecto, os códigos perversos subvertem as relações de poder, deslizando sobre as estruturas que possam oferecer riscos ao gozo. Com essas colocações de Freud, as perversões se ramificaram em representações que dialogam com a necessidade de escamotear as angústias como exibicionismo, voyeurismo, masoquismo, sadismo, como alguns exemplos. Dentro da moral perversa, há também a construção de leis próprias como forma idealizada da representação que possa substituir o falo castrado da mãe: são os objetos fetichizados. O objeto eleito para ser fetiche não apenas seria um amuleto para o sujeito se proteger da angústia provocada pela castração, mas também da decepção causada pelo reconhecimento da ausência fálica materna. Mesmo sendo uma presença constante na moral perversa, a proposta fetichista não

1 De modo sintético, as demais estruturas do psiquismo operam em Verwerfung, quando psicoses (foraclusão) em que o "sujeito não se dá conta da castração, da diferença dos sexos, não há a admissão da lei do pai e a conseqüência é uma estrutura psicótica [e as neuroses] Verdrangung, recalcamento: o sujeito reconhecendo a diferença dos sexos, instaura a falta como intrínseca ao ser humano e a aceita: "lei do pai'. O resultado é a estrutura neurótica" (Pires e outros, 2004, p. 46).

2 O Complexo de Édipo é o processo pelo qual o sujeito enfrenta enquanto uma passagem para o universo cultural e civilizatório, pois estabelece leis e regras como o interdito do incesto, a ameaça da castração, punição e o desejo de matar o pai de modo simbólico (Quinet, 2015). 
se limita apenas a essa estrutura, mas pode ser compreendida nas neuroses e psicoses; o que diferencia uma prática de defesa do ato patológico é a obsessão que se configura pelo desejo ao objeto.

Segundo a proposta de Freud, a adoção do fetiche é realizada quando o objeto é subtraído da sua qualidade de sentido e passa a ser compreendido em uma esfera de individuação de sentido, "uma pura fabricação, uma elaboração [...]. Resta o gozo por uma imagem infinitamente reprodutível, impessoal, dessensibilizada" (Safatle, 2010, p. 54-55). A formação de propostas fetichistas se enquadra em uma porção maior da perversão, que são as realizações de montagens. A ocorrência das montagens não se dá apenas na condição do psiquismo, compreendendo o sujeito e suas subjetividades, mas também nas ações sociais que contemplam indivíduos que não apresentam a perversão como estrutura psíquica, mas estão interessados em usufruir de uma condição para se safarem de privações ou legitimarem seu poder frente ao outro, o que anula qualquer condição de alteridade. Amparada sob o pensamento de Daniel Sibony (1987), Szpacenkopf (2003) acredita que as

\footnotetext{
Montagens perversas são formadas com leis próprias que seus componentes encarnam e se devotam a exercê-las. O que a faz brecha na crença e na lei impõe a criação de uma montagem e de uma programação [...] a montagem é uma relação regida por uma legiferação própria e que supre o que escapa a toda relação: sua lei, sua verdade, sua origem (Szpacenkopf, 2003, p.136).
}

No entendimento dos autores, o perverso é um "fazedor de leis" (Sibony, 1987, p.113). Essa qualidade pode ser interpretada como sendo uma prática segura e também narcísica para se certificar da possibilidade de não enfrentar angústias, pois, amando a si mesmo e mantendo-se fiel aos seus gozos, com a produção de uma moral particular, o perverso evita possíveis percalços. A construção das montagens explicaria as ações de desmerecimento, maus tratos, subestimação e qualificação do outro. Foi pela montagem de pânico e medo, travestida de boas intenções, que ações fascistas emergiram no século XX ou que estruturaram movimentos autoritários e totalitários pelo mundo; houve a promessa de que, se determinados sujeitos (comunistas, homossexuais, judeus, ciganos, deficientes físicos e mentais, entre outros) fossem exterminados, haveria uma melhoria da raça humana, por isso o incentivo à "higienização racial". O que seria isso, se não uma montagem patológica para justificar o império do gozo pelo desmerecimento do outro? 
Além dos experimentos científicos realizados sem quaisquer centelhas de ética, que tinham como cobaias seres humanos e animais, assassinatos construídos com requintes de crueldade, e uma série de episódios que desqualificavam e desmereciam noções elementares de reconhecimento e alteridade. Não há qualquer justificativa que possa ser aventada para o extermínio humano como aconteceu nos regimes totalitários que não fosse fruto de montagem perversa dotada do propósito de aniquilar e varrer da face da terra tudo aquilo que poderia interferir no regimento da execução de leis particulares para o exercício do gozo e benefício próprio ou de uma parcela ínfima da sociedade. Essas considerações são importantes porque elucidam como as perversões também podem ser observadas no meio social, por que têm a necessidade de promover o gozo e nem se quer atribuem atenção àqueles que são diferentes.

Elisabeth Roudinesco (2008) apresenta uma diversidade de passagens históricas que carregam discursos e montagens perversas como a doutrinação religiosa, que objetivava o flagelo humano, as aberrações de exposição de seres humanos e animais ao ridículo, em feiras e parques e, até mesmo, a literatura e vida do Marquês de Sade. A autora também elenca a naturalização de comportamentos e práticas perversos que foram absolvidos dessa qualidade de estigma e são elencados como códigos culturais como, por exemplo, a renitente invasão de privacidade pela mídia, em programas de reality-show, ou a exploração da dor do outro em momentos de vulnerabilidade alheia em programas sensacionalistas e cenas de guerra. É interessante perceber que, mesmo apresentando sinais claros de voyeurismo e exibicionismo, essa programação da mídia se torna socialmente aceita, inclusive, sendo fonte de investimentos economicamente rentáveis, dentro do circuito midiático, como anúncios e patrocínios. Em todos os casos analisados por Roudinesco, é possível reconhecer a prática de esquematização de montagens, uma vez que esses episódios são arquitetados segundo alguma possibilidade de gozo, de anulação de alteridades ou de estratificação de sujeitos no espaço social, uma legislação muito particularizada, comumente praticada de moral perversa.

Reconhecendo os valores e as aplicações desagregantes das perversões no meio social, há também outros olhares que podem ser direcionados aos comportamentos e discursos perversos que não seriam necessariamente nocivos ao espaço social. Muito pelo contrário, seriam movimentos realizados por intenções verdadeiramente libertárias para livrar certos conceitos de estigmas e preconceitos de dentro do universo das representações sociais. Por isso, a denominação, nesse artigo, de montagem perversa positiva. Como os discursos perversos não reconhecem as estruturas de poder, suas propostas 
sugerem enfrentamentos, fazem questionamentos, provocam desaforos, e, inclusive, debocham, com humor e sarcasmo, dessas estruturas previamente estabelecidas. Como também aponta Roudinesco (2008), as propostas perversas, dentro de determinados contextos, podem ser libertárias e muito significantes:

\begin{abstract}
A perversão é também criatividade, superação de si, grandeza. Nesse sentido, pode ser entendida como o acesso à mais elevada das liberdades, uma que autoriza aquele que a encarna a ser simultaneamente carrasco e vítima, senhor e escravo, bárbaro e civilizado. O fascínio exercido sobre nós pela perversão deve-se precisamente a que ela pode ser ora sublime, ora abjeta. Sublime, ao se manifestar nos rebeldes de caráter prometéico, que se negam a se submeter à lei dos homens, ao preço da sua própria exclusão; abjeta, ao se tornar, como no exercício das ditaduras mais ferozes, a expressão soberana de uma fria destruição de todo laço genealógico (Roudinesco, 2008, p. 11).
\end{abstract}

Sob outro aspecto, todavia, não muito diferente, Dufor (2013) também acredita na qualidade desafiadora e destemida de algumas práticas perversas, postulando que essas ações são importantes para a manutenção de um modo saudável de vida, inclusive dentro do sistema político, ao considerar que os insubmissos são necessários, principalmente no campo das artes, em que há mais possibilidades de criação e liberdade:

Eles são necessários nos regimes trancados na sujeição e na submissão. Seja no terreno das artes entre os homens e mulheres. O perverso, com efeito, é aquele que se permite ir olhar onde é proibido, que procede por infração e abre brechas nos sistemas murados (Dufor, 2013, p. 302).

É importante fugir da regra, estabelecer outras propostas de montagens, inclusive para a oferta de novas representações e sentido aos elementos que cercam a vida. Visto por uma ótica semelhante, os desafios às estruturas permanentes são sintomas dos incômodos provocados pela permanência dos poderes instalados. Foucault (1988) observa que há uma relação intensa entre poder e prazer, pois é justamente pela força reguladora de poder que marca corpos e subjetividades que surgem, pelas brechas advindas da disciplina e controle, possibilidades de discursos e comportamentos perversos para realizar combates e enfrentamentos. Segundo o entendimento de Foucault, 
o crescimento das perversões não se torna um assunto moralizador, mas é o resultado da interferência de algum tipo de poder sobre os corpos e os prazeres. Entretanto, é válido frisar que o desenvolvimento das sexualidades periféricas não é necessariamente a difamação ou vingança das estruturas de poder, mas é um efeito-instrumento que surge pela necessidade de livrar-se dos discursos disseminados com propósitos de normalidade. Por esse viés, Esther Díaz (2010) afirma que aqueles que não se encaixam na composição imposta pelas relações de poder-saber, muito possivelmente podem ser enquadrados ao lado de anomalias, patologias, aberrações, perversões:

\begin{abstract}
Mas os diferentes podem ser forçados a gerar seus próprios modelos como condição de possibilidade de acessar instâncias de equalização. Isso não significa negar as diferenças, mas alcançar a paridade política, jurídica, laboral e social. Abrir espaços onde a diferença não seja sujeita à constrição do padrão prevalecente. Exercitar o direito de diferir, não ser idêntico ao molde que é imposto como imperativo, e não pagar um preço duro por isso (p. 82) . $^{3}$.
\end{abstract}

Mesmo não tratando diretamente de signos perversos, Díaz aponta a geração de modelos próprios como saídas para promover igualdades, que é a edificação de montagens e representações perversas para confrontar as marcas do poder.É dentro dessas referências que a revista Nin se encontra com uma intenção perversa de enfrentamento aos signos marmorizados das identidades, prazeres e sexualidades.

\title{
QUEER E A SUA MONTAGEM PERVERSA
}

A revista Nin proclama-se como sendo erótica. Possivelmente, esse seja o único ponto que possa trazer alguma referência identitária à revista carioca. É arriscado delimitar com linhas firmes que a publicação seja voltada a algum público segmentado pelo sexo, identidade ou desejo. Além disso, o leque de representação do corpo, apresentado pela revista, é muito extenso, pois retrata homens e mulheres com sobrepeso, carecas, tatuados, peludos ou depilados, transexuais, homossexuais, lésbicas, ex-profissionais do sexo que lutam para

3 No original: Pero los diferentes pueden esforzarse por generar sus próprios modelos como condición de possibilidad para acceder a instancias igualadoras. Esto no quiere decir renegar de las diferencias, sino lograr paridad política, jurídica, laboral, social. Abrir espacios donde la diferencia no sea sometida a la constricción del patrón imperante Habilitar el derecho a diferir, a no ser idéntico al molde que se impone como imperativo, y no pagar un duro precio por ello (Díaz, 2010, p.82). 
manter a vida fora desse nicho, ou seja, uma gama repleta que não contempla exclusivamente o corpo imaculado e ilibado das representações midiáticas convencionais.

A identidade da revista não é sólida quanto ao delineamento das sexualidades pelas montagens que são feitas de diluição das referências de identidade e prazer. Na mesma edição em que há o ensaio fotográfico de autoria de Paula Faraco, intitulado de Unknown (desconhecido, na língua portuguesa), em que homens e mulheres são retratados nus e nuas, despindo-se ou em detalhes do corpo, dentro de uma ambiência onírica, há também o ensaio de Alessio Boni que mostra um homem nu em cenas do cotidiano de uma casa. Esse ensaio fotográfico acompanha o artigo de Fernanda Marinho sobre as nuances da nudez masculina nas representações artísticas.

- Figura 1 - Ensaio Unknown, de Paula Faraco

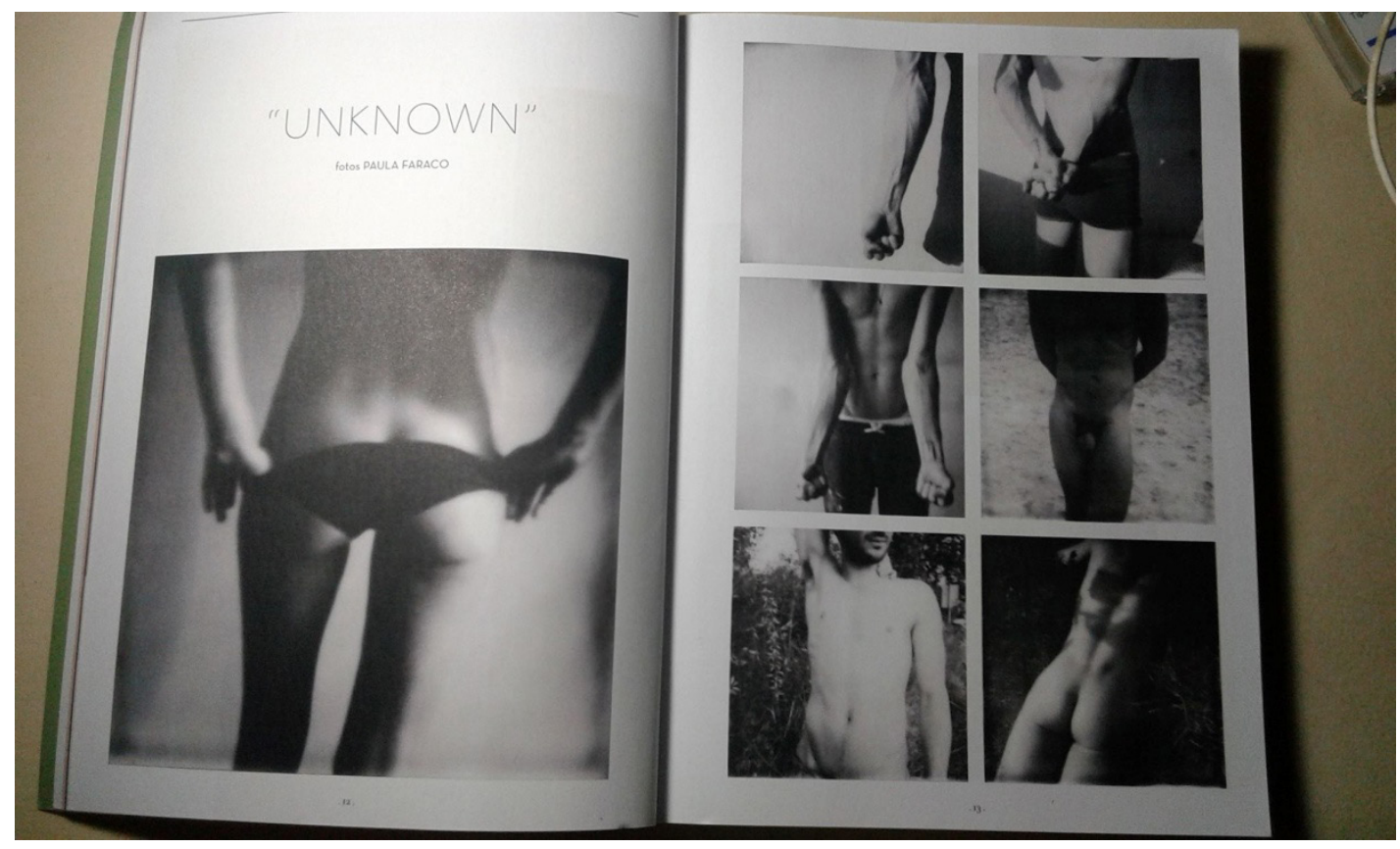

Fonte: Revista Nin, 1 ed. p. 12-13. 
- Figura 2 - Ensaio de autoria de Alessio Boni

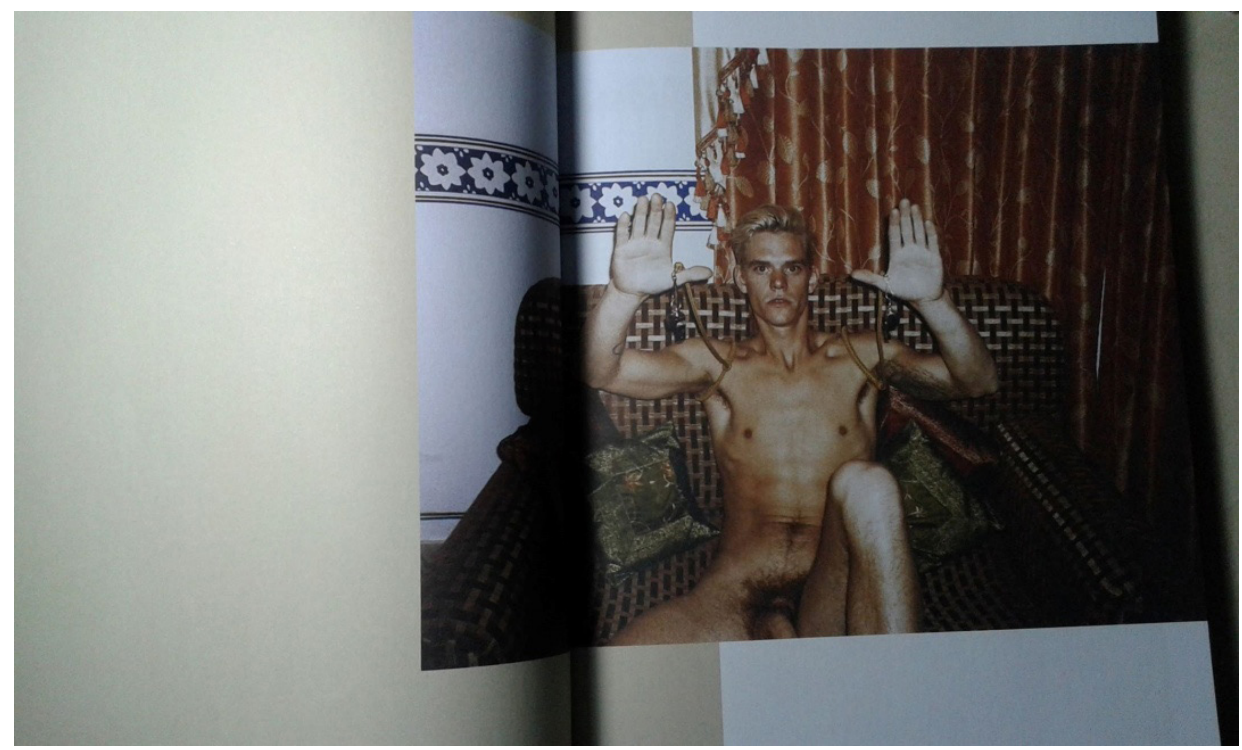

Fonte: Revista Nin, 1ed. p. 34-35.

Mulheres novas e mais maduras dividem espaços no ensaio Pfirsich FicktFeige, (Pêssego fode figo, tradução literal do alemão) de autoria da fotógrafa alemã Eva Baales, em propostas que misturam porções de dadaísmo e surrealismo.

- Figura 3 - Ensaio Pfirsich FicktFeige, de Eva Baales

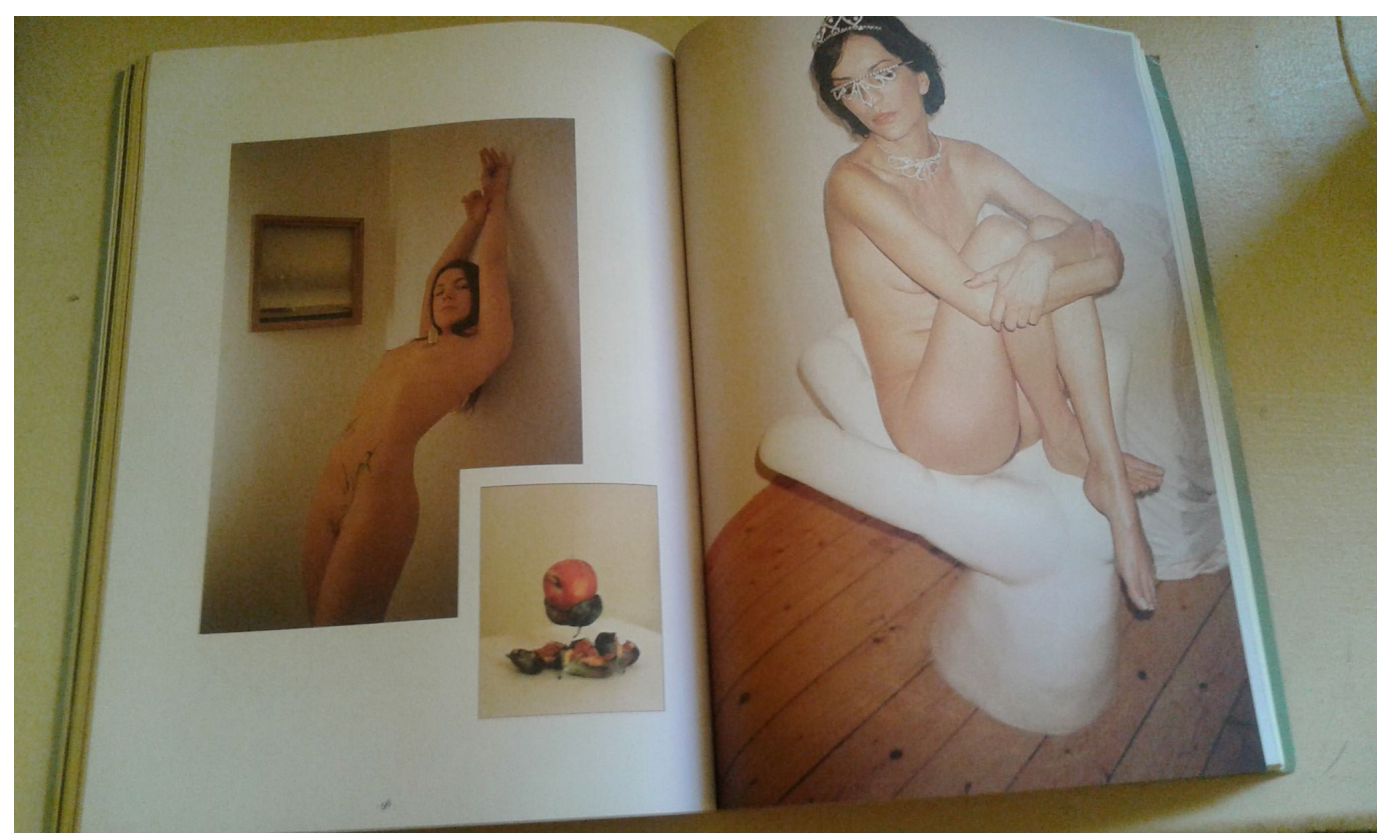

Fonte: Revista Nin, 1 ed. p. 98-99. 
- Figura 4 - Ensaio Pfirsich FicktFeige, de Eva Baales

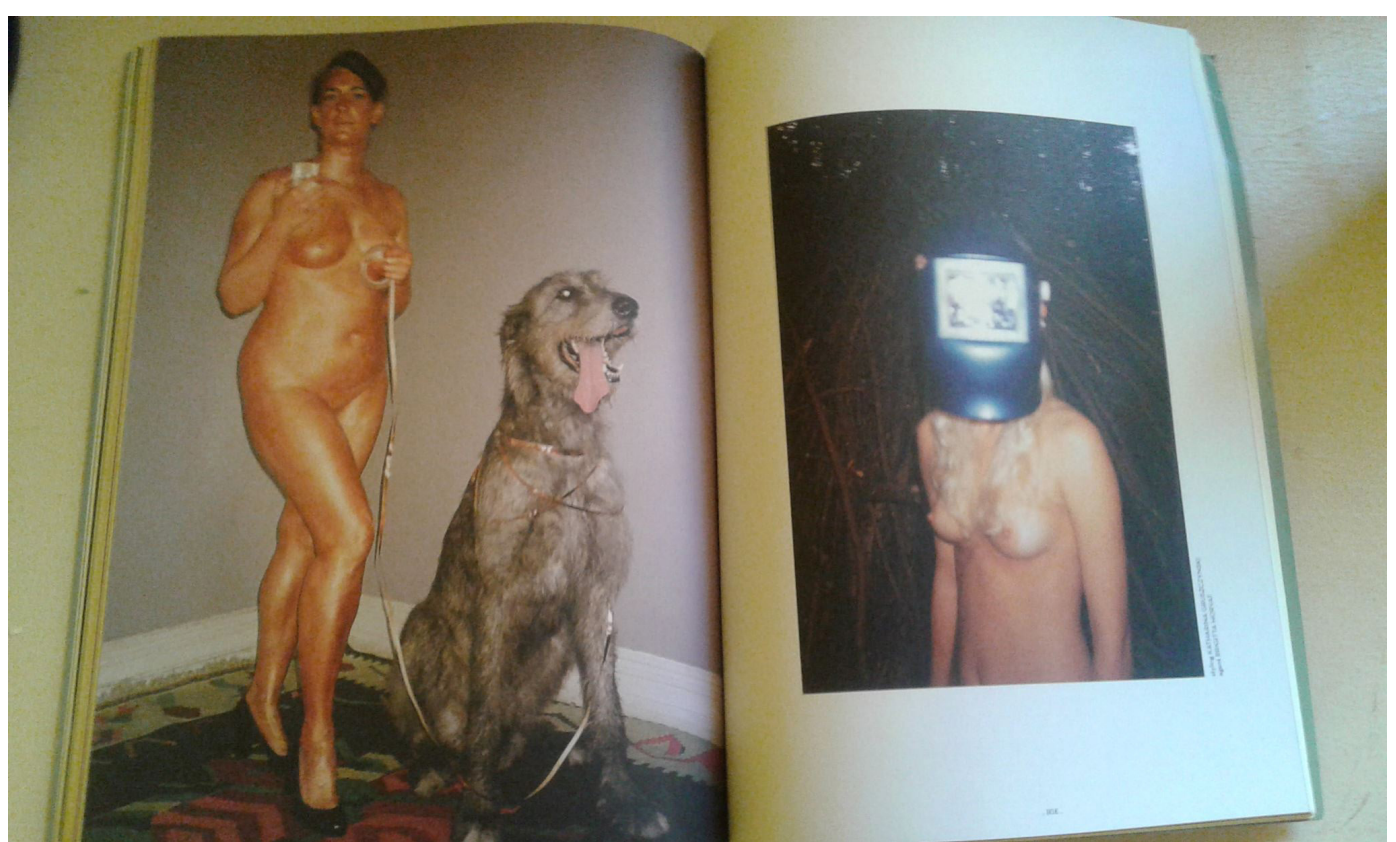

Fonte: Revista Nin, 1 ed. p. 98-99.

Além disso, a revista apresenta uma série de desenhos, cartoons e outras ilustrações que remetem ao lado debochado do sexo, como o desenho de Verena Smit.

\section{Figura 5 - Desenho de Verena Smit}

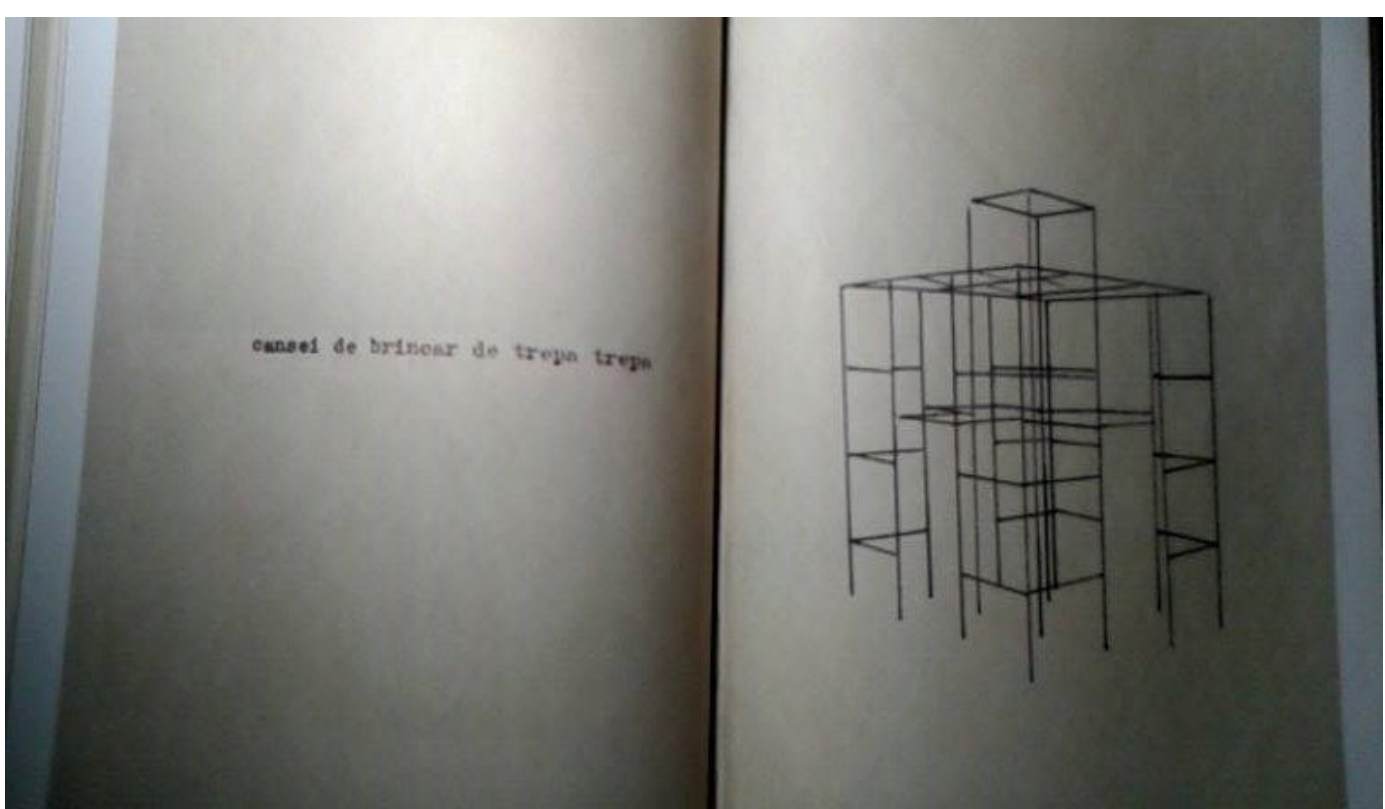

Legenda: "Cansei de brincar de trepa trepa"

Fonte: Revista Nin, 1 ed. p. 78-79. 
O compromisso da revista não está também em apresentar fronteiras aos desejos, tão pouco às representações das identidades e sexualidades; nas páginas da Nin, as referências sobre esses temas não se apresentam cristalizadas, mas em trânsito, em órbita, por vários terrenos que não são fixados por signos tão concretos. Enquanto sintoma de uma qualidade cultural contemporânea, Hall (2010) aponta a transitoriedade dos referenciais identitários devido a fenômenos como a globalização e o advento de novas tecnologias que operam novos códigos morais e também de participação, comunicação e atuação social.

O cerne para as identidades não está mais fixo, havendo possibilidades de tráfego e mudanças, dependendo dos contextos em que os sujeitos estão inseridos. Nin borra os limites do desejo heteronormativo, lésbico ou homoerótico e constrói uma lei particular de representação das sexualidades, uma montagem específica. A mesma percepção se estende para a compreensão dos gêneros e sexualidades, na atualidade. Por isso Joan Scott (1995) afirma que os gêneros estabelecem diálogos francos com o período histórico. Dessa forma se fazem necessários novos processos políticos que reinventem as qualidades morais e os modos de representação das sexualidades; processos esses que ora avançam ou refratam nas representações, mas que estão em constantes conflitos no cenário social para alegar posicionamentos, papeis e, até mesmo, subverter qualidades já estabelecidas.

Com outro panorama, pós-estruturalista, Preciado ${ }^{4}$ (2014) acredita que há uma tecnologia social baseada nas concepções heteronormativas que estabelecem como devem ser, parecer e dinamizar os sexos enquanto discurso biopolítico de controle e disciplina do corpo, desejo e subjetividades. Todavia, para Preciado, não é no recorte biológico do corpo que se encontra a identidade do gênero ou sexo, mas nos efeitos de reinscrição das práticas do gênero nesse corpo, ou seja, o modo como o indivíduo cria, recria, nega e afirma suas convicções. Assim, em sua concepção, o gênero vai um pouco além da performatividade, conceito desenvolvido por Judith Butler (2003), que concebe o gênero como sendo um efeito das práticas culturais linguístico-discursivas. Preciado não anula o entendimento de Butler, mas se posiciona argumentando que o gênero está para além do corpo, além da pele que envolve a carcaça orgânica e pontua que

o gênero é, antes de tudo, prostético, ou seja, não se dá senão na materialidade dos corpos. Foge das falsas dicotomias metafísicas

4 Até 2015, Preciado tinha como primeiro nome Beatriz; após aquele ano, é denominado como Paul B. Preciado. 
entre o corpo e a alma, a forma e a matéria. [...] O gênero poderia resultar em uma tecnologia sofisticada que fabrica corpos sexuais (Preciado, 2014, p. 29).

Mesmo sugerindo a rebeldia do gênero, Preciado não acredita no desaparecimento das referências entre homem/mulher, heterossexual/ homossexual, por exemplo. Entretanto, aponta que existem outras possibilidades de representações que fogem das dicotomias e que se alojam fora da perspectiva de poder. Essa é uma intenção que, sendo transgressora, colabora para o espaço social, pois é libertária como uma proposta de vivência para as sexualidades e prazeres e, também, por não estar associada às estruturas de poder; pelo contrário, revolta-se, forja e oferece outra nuance de pensamento e compreensão. Essa proposta de subversão de identidade e signos da sexualidade é o que representamos como queer, a desordem das referências previamente esquematizadas pela fragmentação e dissolução dos elementos de identidade. O termo de origem da língua inglesa significa estranho, esquisito, repugnante; para os estudos das sexualidades, esses adjetivos, na verdade, expressam os traços que operam fora do quadro considerado normativo e, por isso, localizamse o limbo das representações, o que não quer dizer que não tenham valor social ou que não ofereçam uma riqueza de possibilidades de representações das sexualidades.

Uma epistemologia que nasceu nos Estudos Culturais e dos movimentos feministas e pós-estruturalistas questiona a fixação rígida dos elementos conjugados entre sexo/gênero/identidade, deixando-a livre dos referenciais de propostas cartesianas, até mesmo afastando-as dos discursos biologizantes (Miskolci 2009). Como aponta Silva (2000), o queer tem natureza perversa, porque faz "questionar, problematizar, contestar todas as formas bem-comportadas de conhecimento e de identidade. [...] é, neste sentido, perversa, subversiva, irreverente, profana, desrespeitosa"(Silva, 2000, p.107). São esses os movimentos que vão desenhar as montagens da revista Nin com o intuito de evidenciar como o olhar perverso de desafio pode contribuir para o enriquecimento das representações de sexualidade.

A primeira edição da revista, de 2015, trouxe como assunto de capa a entrevista com a ex-atriz pornô Cicciolina, nome artístico de Ilona Staller, húngara de nascença. Foi na Itália onde teve projeção internacional pelos filmes protagonizados e pela carreira política, quando integrou o Parlamento italiano, em 1987. Cicciolina questiona a representação da mulher nos discursos midiáticos que as coloca em paridade com meros objetos de consumo para saciar a vontade masculina e acredita que as representações das mulheres 
podem ser feitas com o propósito do erotismo e nudez, todavia, não alicerçados em estereótipos.

Como possibilidade de luta contra os estereótipos, os autorretratos de Lídia O. ilustram o artigo de João da Matta (2015) Erotismo, sensualidade \& sensualidade como potências da vida. O artigo trata, a partir das considerações de Wilhelm Reich, "da importância do exercício pleno da sexualidade como arma revolucionária, capaz de promover uma intensificação da vida" (p. 65). $\mathrm{Na}$ opinião de Matta, o adoecimento do corpo estaria relacionado à presença de discursos moralizantes e ações antilibidinais e por isso, a psicologia poderia caminhar lado a lado da análise crítica para questionar forças de poder e promover a revolução social e sexual. Em outra passagem, o autor considera que as experiências eróticas fazem parte da vida cotidiana do sujeito como na alimentação e nos laços de amizades, por exemplo; caso o sujeito tivesse noção do prazer que essas ações possam causar, se libertaria de certas convenções sociais porque seriam desenvolvidos outros afetos que não fossem aqueles regidos pela ordem de governança de comportamentos.

As fotografias de Lídia O. dialogam com as intenções de Matta e também de Cicciolina. Retratada nua no sofá, ela expõe seu corpo, sua genitália, seios e pernas. Essa montagem aparentemente em nada difere das demais revistas eróticas que trazem mulheres nuas nas páginas, se não fosse o caso dela ser uma mulher acima do peso, de pele melânica, com os cabelos raspados, que carrega algumas tatuagens pelo corpo e não apresenta nenhum traço do estereótipo de delicadeza tão expresso nos discursos acerca das mulheres nas representações midiáticas convencionalmente conhecidas.

- Figura 6 - Ensaio de Lídia 0.

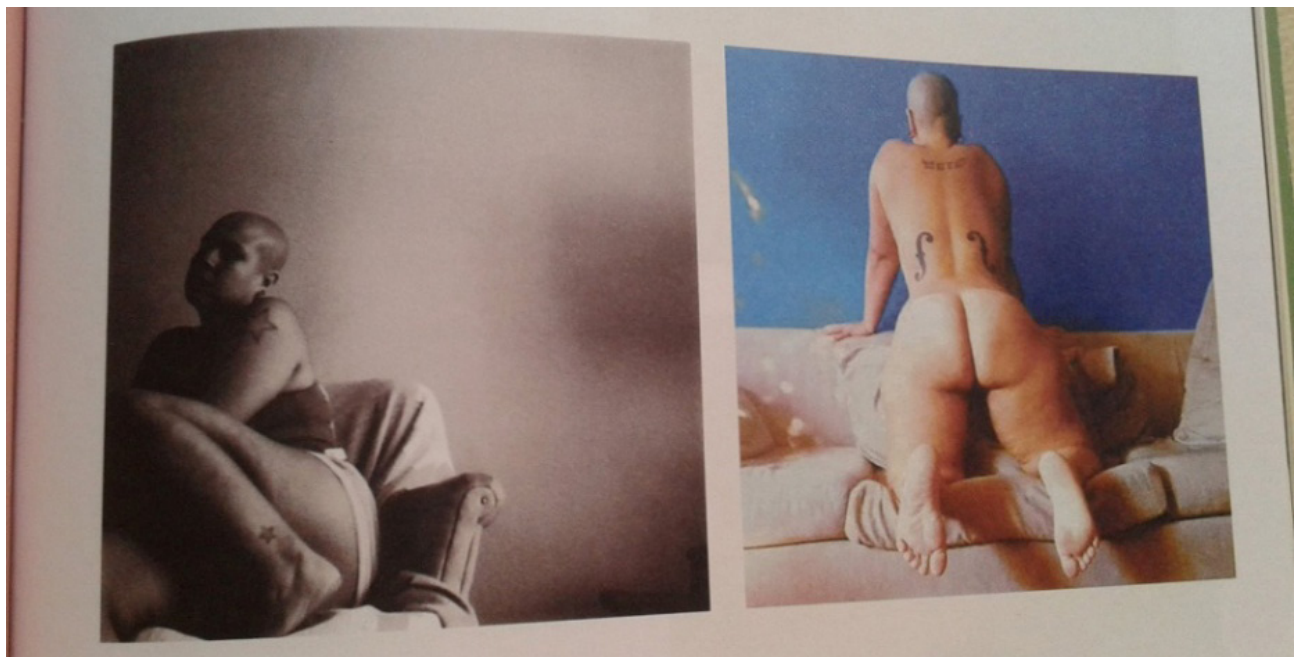

Fonte: Revista Nin, 1 ed. p. 63. 
- Figura 7 - Ensaio de Lídia 0.

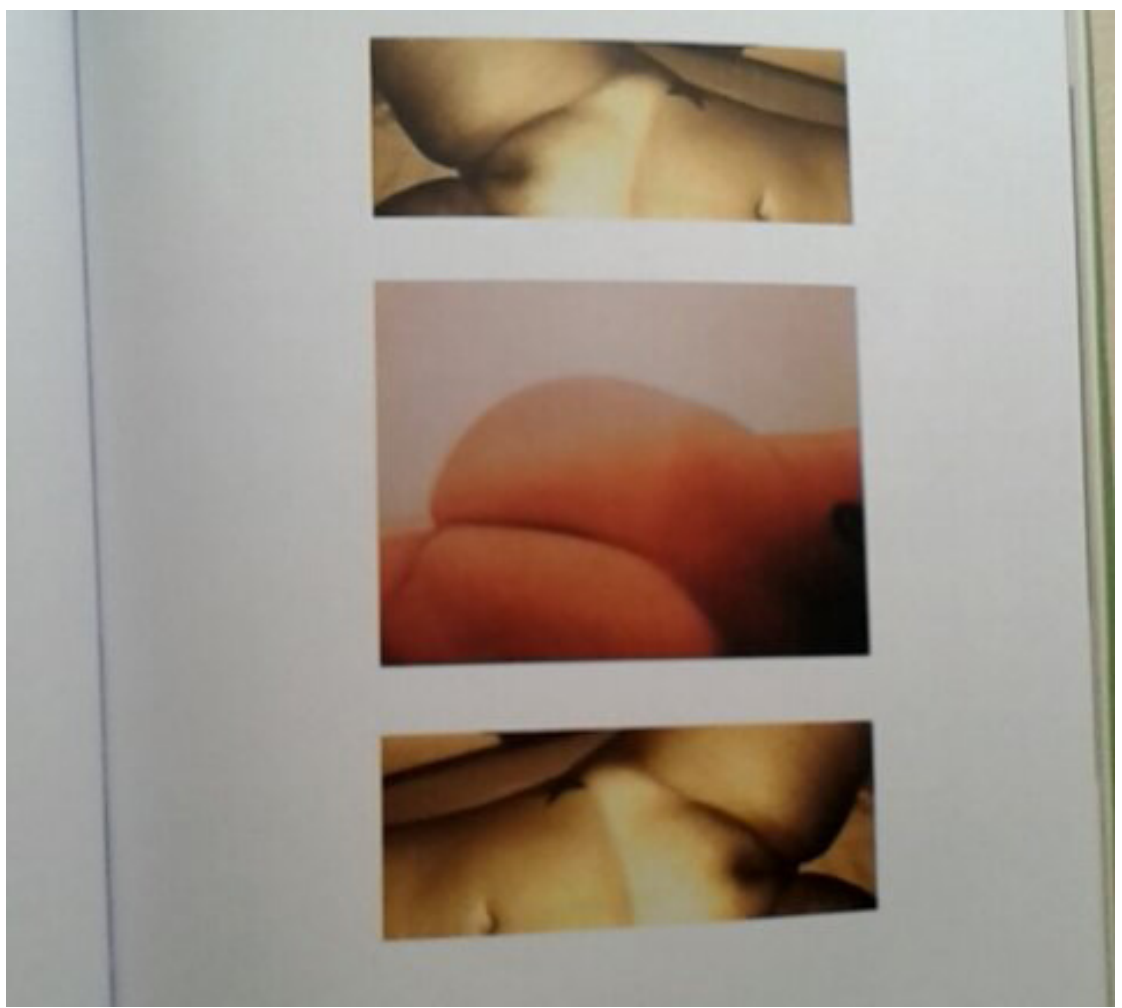

Fonte: Revista Nin, 1 ed. p. 64.

- Figura 8 - Ensaio de Letícia 0.

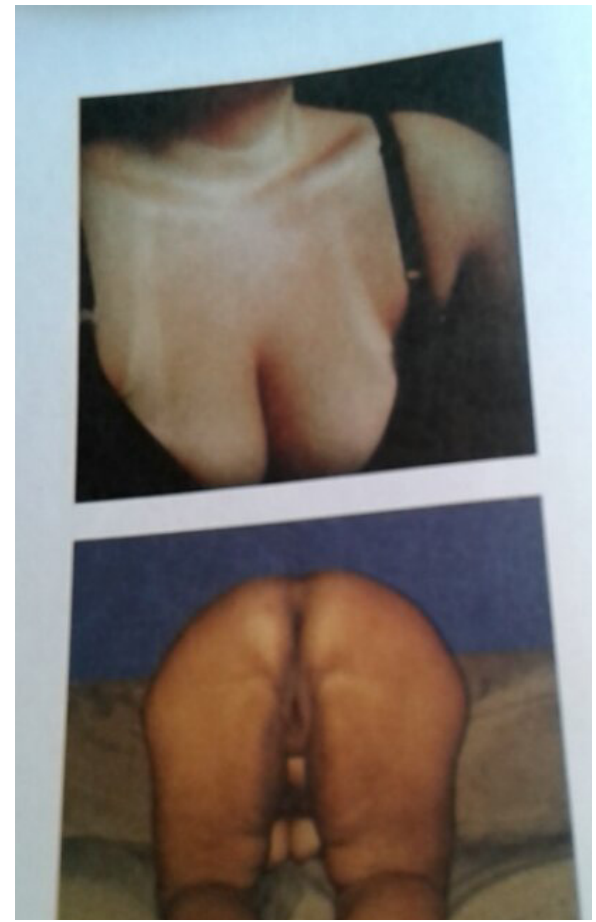

Fonte: Revista Nin, 1 ed. p. 65. 
Corpulenta e fora das qualidades do corpo liso e sem vilezas, as representações de Lídia $O$. são desafiadoras por oferecer o contraponto aos ditames de controle e disciplina do corpo, principalmente sobre o que tange as representações midiáticas. Essas fotografias não são erradas ou equivocadas. Tão pouco carregam signos que mereçam desqualificações, mas apresentam sinais perversos por assumirem o desaforo de uma condição cristalizada do corpo, sexualidade e gênero daquilo que seria socialmente aceito enquanto um discurso de uma revista. Nesse caso, as fotografias dispõem de montagens que lidam com outra proposta de desejo e de prazer: trazer à tona o incômodo guardado como recalque, aquilo que perturba e é deixado à revelia nos modos de representação midiáticos. Não caberia ao corpo denso, marcado por estrias, celulites e gorduras localizadas, a exposição de modo tão explícito aos olhos alheios, como apresenta Sibilia (2006), em que determinadas marcas do corpo são dignas de repúdio e aversão, "sempre ameaçadas de caírem no domínio das monstruosidades e das aberrações. Ou quiçá, pior ainda: da invisibilidade" (Sibilia, 2006, p. 277).

A montagem semelhante foi utilizada nas imagens produzidas nos textos @ex_miss_febem é Aleta Valente bangu, de autoria de Letícia Gicovate (2016); e Aleta Valente, a boca do novo mundo, de Alessandra Colassanti (2016). Essas produções fazem parte da segunda edição da revista, de 2016, que trouxe também o ensaio sensual de Camila Ribeiro, modelo transexual que relatou algumas de suas experiências. Os textos e imagens apresentam Aleta Valente, nome artístico de Aleta Gomes Vieira, que também adota a denominação de Exmiss Febem, título da página que mantém na rede social Instagram. O destaque que ela ganhou foi com a fotografia em que mostra uma vagina aparentemente com sangue menstrual com a legenda L'origine du nouveau monde (A origem do novo mundo, traduzindo do francês), uma forte alusão ao quadro famoso A origem do mundo, de Coubert, pintado em 1866, que mostra uma vagina exposta. 
- Figura 5 - Ensaio de Aleta Valente "L'origine du nouveau monde"

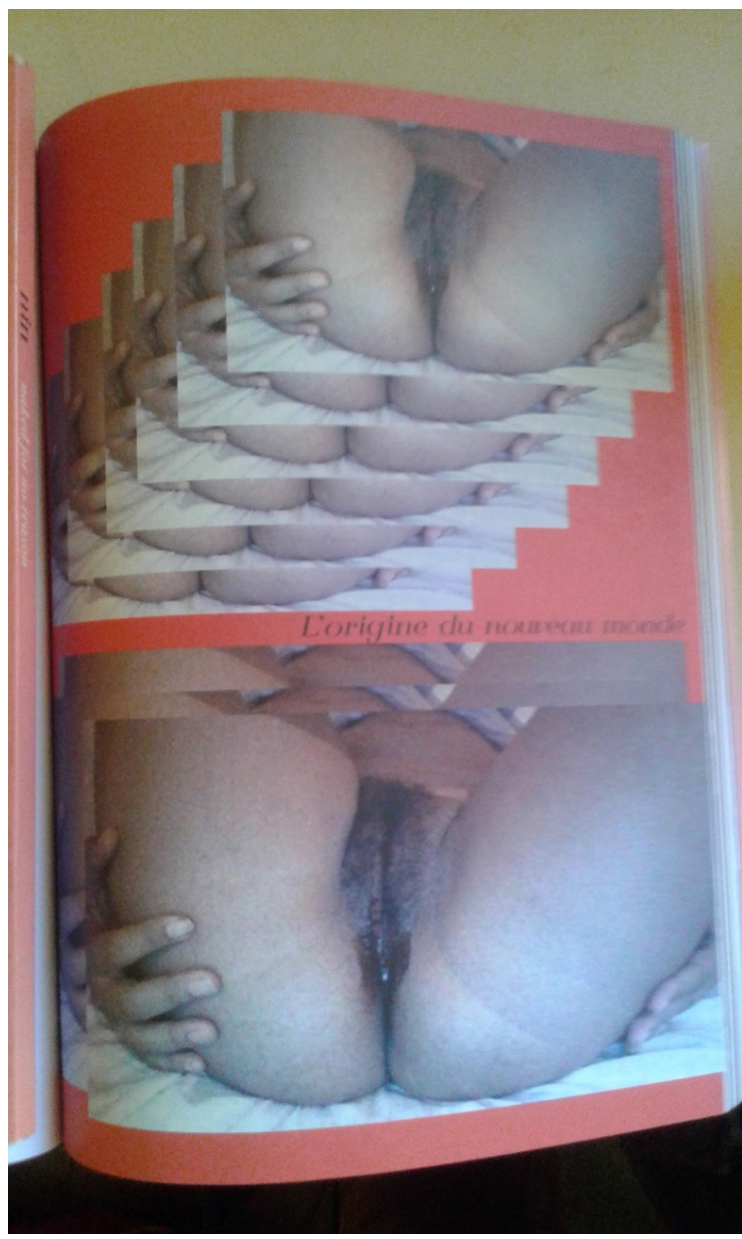

Fonte: Revista Nin, n. 2, p. 63.

A artista debocha, choca, entretém e subverte a estética das fotografias de nudez feminina, quando traz aos olhos dos leitores aspectos tão íntimos como menstruação, nudez e depilação na composição de suas imagens. Artista plástica formada pela Universidade Federal do Rio de Janeiro (UFRJ), moradora da periferia carioca, mais precisamente Bangu, enfrentou a loucura da mãe, a maternidade precoce e outras adversidades que se podem encontrar, sendo vizinha do complexo penitenciário que a cerca. "Aleta é artista [...] e marginal, mesmo se não quisesse ser" (Gicovate, 2016, p.39). Ela mostra seus pelos na axila, o descoloramento dos cabelos se expondo semi-nua ao sol e não tem qualquer pudor ao exibir a própria vagina. Ela faz do exibicionismo um dos elementos primordiais de montagem perversa, uma prática intensa para enfrentar os paradigmas muito concretos para a expressão da sua arte, do corpo e da sexualidade. 
- Figura 6 - Ensaio Aleta Valente

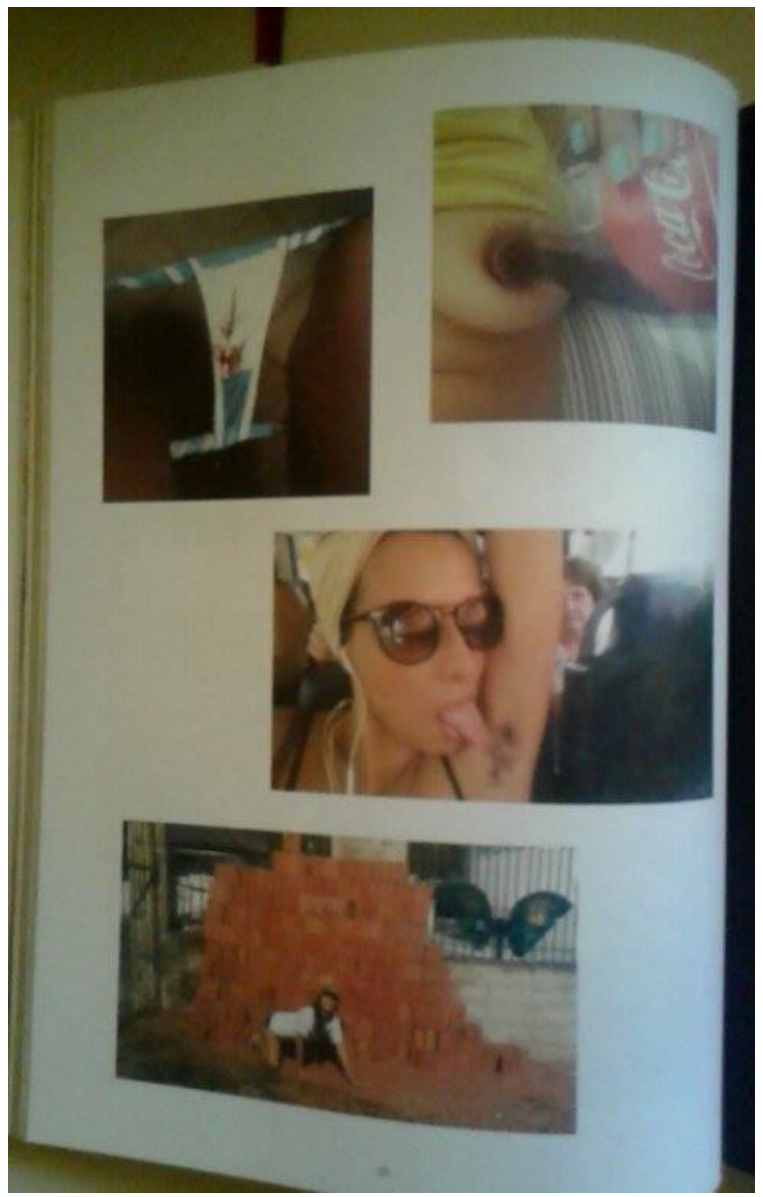

Fonte: Revista Nin, n. 2, p. 58.

Gicovate (2016) considera que a sua "imagem não encontra limites" (p. 39). Não perceber os limites é justamente uma das características mais marcantes dos discursos e práticas perversos:

[...] Cansou de carregar estigma nas costas e passou a esfregá-los na própria cara, na bunda perfeita, nos peitos prontos e nos braços fortes de mãe. Ela não supera o estigma. Ela faz você querer foder com ele. Aleta Valente é Ex-Miss Febem. O sangue da Ex-Miss Febem se espalha pela buceta, pela calcinha, na cama, no visor, seus peitos procuram na tela o ângulo que não mostre as marcas da maternidade, as dentadas da vida. Ou mostre, que se foda, que me fodam, que foda quem quiser foder [...] (Gicovate, 2016, p.39).

Ainda enquanto uma montagem perversa, as fotografias de Aleta trazem à tona os elementos que deveriam ser rejeitados, aniquilados, estigmatizados 
sob a ordem da imoralidade, mas fazem dele mais um caminho para a oferta do erotismo, do prazer, do deboche e do escárnio. A proposta da montagem da artista é rizomática, no sentido atribuído por Deleuze e Guatarri (1995), já que essas representações não se encontram em parâmetros rígidos da beleza convencional, mas na qualidade estética do choque e da subversão, ações típicas do universo perverso. As representações rizomáticas não acontecem em discursos cristalizados, mas em propostas de fugas. As referências estéticas das fotografias de Aleta não se encontram estanques, mas em construções de ações de multiplicidades com aquilo que seria grotesco e aberrante, como as secreções do corpo, pelos em axilas e menstruação, sujeitos marginalizados socialmente, espaço árido da periferia para oferecer uma outra proposta de erotismo. Compreender a multiplicidade, nessas fotografias, é perceber que elas subverteram a ordem dos elementos comumente adotados ao prazer da imagem de uma mulher nua em uma revista; destarte, cabe à multiplicidade, pelo rizoma, ser estranha "a qualquer ideia de eixo genético ou de estrutura profunda [...] Comunicações transversais entre linhas diferenciadas embaralham as árvores genealógicas [...] O rizoma é uma antigenealogia" (Deleuze; Guatarri, 1995, p. 28-29), ou seja, pode haver uma saída para outras representações. O rizoma não traz acomodações, totalizações, massificações, mas aventa a instabilidade de significações flutuantes, inversões e transitoriedade.

Étambém relevante e salutar que a proposta rizomática de multiplicidades requer a realização de agenciamentos para o crescimento das dimensões das próprias multiplicidades, realizando mais conexões. Todavia, isso não quer dizer que os signos gerados pelas novas interfaces tenham uma dimensão superior às existentes: "ao contrário, da maneira simples, com força de sobriedade, no nível das dimensões de que se dispõe, sempre n-1 (é somente assim que o uno faz parte do múltiplo, estando sempre subtraído dele). Subtrair o único da multiplicidade a ser construída"(Deleuze; Guatarri, 1995, p. 21). Com isso, não são estabelecidas hierarquias, mas outras propostas discursivas de representação. Oferecer pelos, sangue e marginalidade, além de fazer parte de uma montagem perversa, também pode ser uma possibilidade de prazer pela contravenção.

Sob outro olhar, assim com as fotografias de Lídia O., Aleta Valente debocha e ridiculariza as estruturas formadas, tanto por ilustrar cenas da periferia do Rio de Janeiro, como também os traços fortes de machismo, fazendo dessas iniciativas movimentos políticos de visibilidade e reconhecimento social. Como apresenta Colassanti (2015), 
[...] com fins de protesto, uma performance cotidiana com fins de crítica social, uma performance em processo que confronta as normas culturais vigentes, com vistas a uma transformação da realidade, a libertação do corpo da mulher, a dissolução da ideologia machista dominante e o fim das minorias (Colassanti, 2015, p.63).

A potência criativa das suas montagens se dá justamente pelos referenciais simbólicos da transgressão, por incomodar os discursos tão praticados que incrustam os parâmetros morais de normalidade e insanidade. Todavia, suas fotografias recheiam o cotidiano de muitos homens e mulheres, não apenas nas periferias, mas, em espaços públicos ou "inadequados" para a situação retratada:

\begin{abstract}
Seu estilo destemido e dissonante ilumina uma série de subjetividades periféricas, expõe o corpo e a sexualidade da mulher de maneira inaceitável para a cultura heteronormativa, explicita uma atitude que o ideário patriarcal-machista-misógeno faz questão de esconder, condenar, oprimir, apagar, castrar. Aleta desafia a tradição, cria ruído, tremor e horror nas depiladas redes sociais com sua tempestade de bucetas, pentelho, sovacos, sangue, drogas, pegação, gays, entulhos, caos, calcinhas, quentinhas e coxinhas de galinhas. No seu Instagram, Bangu é o centro do mundo e marginal é o Leblon (Colassanti, 2016, p. 63).
\end{abstract}

Os movimentos perversos da revista se articulam na intenção de esmorecer os paradigmas que não se sustentam com a força da estereotipação, acrescentando o deboche e o escárnio, elementos fundamentais para a construção de propostas subversivas, destemidas e arrojadas.

\title{
CONSIDERAÇÕES FINAIS
}

As montagens contidas na revista Nin podem até chocar pelas construções poéticas dos discursos e imagens, todavia esse modo de produção torna-se perverso quando não reconhece as estruturas rígidas de poder e traz à tona outros caminhos possíveis para a sexualidade, o desejo e a fantasia, ainda mais pelo viés do deboche e de irreverência. As montagens perversas da Nin agridem os olhos e as percepções mais conservadores ao elencar pelos, sangue, drogas, travestis, vaginas e pênis. Entretanto, essa proposta se torna um alegoria para o escárnio pelo enfrentamento dos códigos instaurados socialmente. Esse movimento também carrega consigo ações políticas porque, 
além do embate oferecido, retiram da sombra sujeitos e referências que se encontrariam no limbo de representações para oferecer visibilidade e destaque aos olhos públicos. Elencar todas as montagens perversas positivas, no campo da comunicação e artes, é algo quase impossível, uma vez que essa qualidade é renitente à condição humana. A montagem perversa positiva sempre existiu porque sempre houve a necessidade de enfrentamento de poderes vigentes.

Nin não é a primeira publicação brasileira a fazer esse tipo de montagem. Aliás, são nos discursos das artes, da academia e em revistas que apresentam essa diferenciação editorial que as perversões ganham mais liberdade e possibilidades de serem vistas, podendo ser apreciadas, comercializadas e reverberadas como alternativas de representações dentro de contextos engessados. Enquanto nos séculos XIX e XX houve a exploração de deficientes físicos e da mazela humana em parques e exposições, como práticas perversas de desmerecimento do outro, há também a possibilidade de reconhecer as perversões como manifestações políticas e que podem ser absorvidas como ações agregadoras ao espaço social, a despeito de serem comercializadas.

Como sinais de perversões positivas, podemos elencar também o jornal Lampião da Esquina, o primeiro jornal homoerótico alternativo que circulou no Brasil. A publicação fazia outro tipo de enfrentamento para oferecer reconhecimento social a homossexuais, lésbicas, ambientalistas, feministas, negros e outras fatias sociais consideradas como sendo minorias, por uma questão de poder. $\mathrm{O}$ deboche de Lampião estava no discurso de refutação das forças discriminatórias e das ações de repressão e censura que ainda insistiam em circular no país, no final dos anos de 1970. Possivelmente, a maioria dos veículos alternativos, principalmente os que circularam durante a vigência da ditadura civil-militar brasileira, trariam os traços de uma montagem perversa, seja pelo deboche, seja por que não reconheciam o poder em vigor como suficientemente castrador.

Enquanto produções artísticas, as montagens perversas positivas estão mais claras. Como exemplo, temos o painel composto pelas obras Jardim das delícias terrenas, O inferno e O jardim do Éden, de Hieronymus Bosch. Pintado em 1504, o conjunto apresenta cenas de sexo, prazeres e gozos como modo de retratar os castigos e as delícias da vida terrena e as conseqüências de uma vida de luxúria.

As fotografias e filmes de Andy Wahrol, que retrataram drag-queens, prostitutas e garotos de programas e outras figuras marginalizadas socialmente, até mesmo suas pinturas podem ser consideradas perversas quando debocham do capitalismo e da sociedade de consumo. As produções da pornochanchada brasileira, mesmo com algumas propostas conservadoras, 
também apresentaram traços de transgressão quando evidenciam elementos e temas como a homossexualidade, traição, transexualidade e desejo nas telas do cinema, assuntos recalcados de modo persistente, até então, no cinema nacional (Amaral, 2016). O mesmo vale para a produção literária de Nelson Rodrigues, o Anjo Pornográfico, que construiu montagens perversas, ora de deboche, ora de crítica (quando não as duas medidas) para retratar a hipocrisia e o conservadorismo da sociedade brasileira.

Há também os romances eróticos de Cassandra Rios e Adelaide Carraro, que escandalizaram uma geração brasileira ao expor a sexualidade de forma tão intensa e sem meandros. Até as histórias em quadrinhos de cunho erótico dos "catecismos" de Carlos Zéfiro, durante as décadas de 1950 e 1970, podem ser compreendidos como montagem perversa positiva, pois esse tipo de "produção trouxe uma nova forma de se relacionar com as revistas, dando aos brasileiros, não só uma revista, mas um manual de como pensar e fazer o sexo, dando ao Brasil lugar para a discussão de sexualidades periféricas" (Ribeiro; Souza, 2016, p. 376-377), as pequenas publicações de Zéfiro pretendiam oferecer erotismo às camadas subalternas da sociedade, a baixo custo.

No cinema, a lista de produções com nuances perversas positivas contempla a produção do cineasta Tinto Brass, com os filmes Calígula (1979), que retrata a vida do imperador romano e suas recorrentes orgias sexuais; é também de Brass o filme A pervertida (2000), que conta a vida erótica e secreta de Carla. A perversão, no cinema, também se encontra no filme Pink flamingos (1972), com direção de John Walters, que mostra a rivalidade entre duas famílias, sendo que o mérito é reconhecer qual família seria mais perversa. A obra ganhou destaque no cinema underground e deu visibilidade à drag-queen Divine, quando ela pratica incesto com o irmão e ingere fezes caninas. Essas poéticas visuais tornam-se perversas na medida em que trazem à luz novas estéticas e percepções para o cinema.

Há, pelo mundo afora, uma diversidade de montagens positivas que segue a necessidade de perverter a ordem, incomodar e ressignificar valores. Nin integra uma dessas montagens como uma possibilidade de subversão de valores. A revista só existe porque, na mesma proporção, existe um discurso igualmente perverso, mas de outra natureza, que insiste em disciplinar e controlar corpos e subjetividades. Nin é sintoma dessa qualidade, por isso a necessidade de construir discursos que desaforam e escapam dos rituais litúrgicos que permanecem nos meandros de uma sociedade conservadora com discursos moralistas e retrógrados. As montagens positivas, mais que interessantes, são importantes e necessárias para o ciclo da vida, em nome da variedade de experiências estéticas que são possíveis de realizar, entrando em contato com o 
desconhecido, com o diferente, e tendo uma experiência sinestésica até então não vivenciada. Ao fim e ao cabo, ficamos com o pensamento de Elisabeth Roudinesco, ao mencionar a importância de certos perversos, no mundo, como sendo manifestações:

\begin{abstract}
Ao mesmo tempo em que preserva a norma, assegura à espécie humana a subsistência de seus prazeres e transgressões. Que faríamos sem Sade, Mishima, Jean Genet, Pasolini, Hitchcock e muitos outros, que nos deram as obras mais refinadas possíveis? Que faríamos se não pudéssemos apontar como bodes expiatórios - isto é, perversos - aqueles que aceitam traduzir em estranhas atitudes as tendências inconfessáveis que nos habitam e que recalcamos? (Roudinesco, 2008, p.13).
\end{abstract}

Por isso, as perversões podem ser manifestações políticas, no intuito de promover o reconhecimento de uma gama de atores sociais. As perversões são trans-históricas porque não pertencem a um único momento da história. Além disso, e não menos importante, elas são inerentes à condição humana, sendo fundamentais no ciclo da vida.

\title{
REFERÊNCIAS
}

AMARAL, Muriel Emídio Pessoa. As representações de perversões e estereótipos no filme "Macho, fêmea e cia - a vida erótica de Caim e Abel". In: BERTOLLI FILHO, Claudio; AMARAL, M.E.P. (orgs.). Pornochanchando: em nome da moral, do deboche e do prazer. São Paulo: Cultura Acadêmica, 2016. p. 121-138.

BUTLER, Judith. Problema de gênero: feminismo e subversão de identidade. Rio de Janeiro: Civilização Brasileira, 2003.

COLASSANTI, Alice. Aleta Valente, a boca do novo mundo. Nin, Rio de Janeiro, ed. 2, ano 1, p. 62-65, 2015.

DOR, Jöel. Estrutura e perversão. Porto Alegre: Artes Médicas, 1991.

DUFOR, Dany R. A cidade perversa: liberalismo e pornografia. Rio de Janeiro: Civilização Brasileira, 2013.

FERRAZ, Flávio C. Perversão. São Paulo: Casa do Psicólogo, 2000.

FOUCAULT, Michel. A história da sexualidade I: a vontade de saber. Rio de Janeiro: Graal, 1988. 
FREUD, Sigmund. Um caso de histeria: três ensaios sobre sexualidade e outros trabalhos. Rio de Janeiro: Imago, 1996.

Neurose, psicose, perversão. Belo Horizonte: Autêntica, 2016.

GICOVATE, Letícia. @ex_miss_febem é Aleta Valente Bangu. Nin, Rio de Janeiro, ed. 2, ano 1, p. 62-65, 2015.

DELEUZE, Gilles; GUATARRI, Fêlix. Mil platôs. In: Capitalismo e Esquizofrenia. v.1. Rio de Janeiro: Editora 34, 1995.

HALL, Stuart. A identidade cultural na pós-modernidade. Rio de Janeiro: DP\&A, 2010.

LANTERI-LAURA, Georges. Leitura das perversões. Rio de Janeiro: Zahar, 1994.

MATTA, João da. Erotismo, sensualidade \& sexualidade como potências da vida. Nin, ed. 1, ano 1, p. 65-67, 2015.

MISKOLCI, Richard. A teoria queer e a sociologia: o desafio de uma analítica da normalização. Revista Sociologias, Porto Alegre, v. 21, n. 1, p. 150-188, 2009.

PIRES, Andréa Lucena de Souza; e outros. Perversão- estrutura ou montagem? Revista Reverso, Belo Horizonte, v. 26, n. 51, p. 43-50, 2004.

QUINET, Antonio. Édipo ao pé da letra: fragmentos de tragédia e psicanálise. Rio de Janeiro: Zahar, 2015.

PRECIADO, Beatriz. Manifesto contrassexual. São Paulo: n-1 edições, 2014.

RIBEIRO, Anderson Francisco; SOUZA, Antônio Carlos. O lugar da pornografia na sociedade brasileira: as guerras públicas e o direito ao erótico (1964-1985). Revista História \& Perspectivas, Uberlândia, v. 29, n. 55, p. 373-400, 2016.

ROUDINESCO, Elisabeth. A parte obscura de nós mesmos: uma história dos perversos. Rio de Janeiro: Zahar, 2008.

SAFATLE, Vladimir. Fetichismo: colonizar o outro. Rio de Janeiro: Civilização Brasileira, 2010.

SCOTT, Joan Wallach. Gênero: uma categoria útil de análise histórica. Educação \& Realidade, Porto Alegre, v. 20, n. 2, p. 71-99, 1995.

SIBILIA, Paula. O bisturi de software: como fazer um "corpo belo" virtualizando a carne impura? In: ARAUJO, Denise Correa (org.). Imagem (Ir) realidade: comunicação e hipermídia. Porto Alegre: Sulina, 2006. p. 271-289. 
SILVA, Tomaz Tadeu da. Documentos de identidade: uma introdução às teorias do currículo. Belo Horizonte: Autêntica, 2000.

SIBONY, Daniel. Perversion: dialogues surdes folies "actuelles". Paris: Édittions Grasset \& Fasquelle, 1987.

SZPACENKOPF, Maria Izabel de Oliveira. $\mathbf{O}$ olhar do poder: a montagem branca e a violência no espetáculo telejornal. Rio de Janeiro: Civilização Brasileira, 2003.

Recebido em: 14/03/2017

Aceito em: 29/05/2017

Dados dos autores:

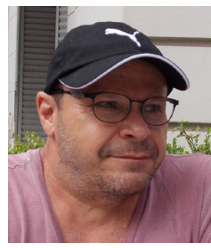

José Miguel Arias Neto <jneto@uel.br>

Professor do Programa de Pós-Graduação (Mestrado) em História Social da Universidade Estadual de Londrina e do Programa de Pós-Graduação em História e Regiões da Universidade do Centro-Oeste do Paraná - (UNICENTRO). Doutor em História Social pela Universidade de São Paulo (2001).

Programa de Pós-Graduação (Mestrado) em História Social

Universidade Estadual de Londrina

Rodovia Celso Garcia Cid, Km 380, s/n - Campus Universitário

86057-970 - Londrina/ PR

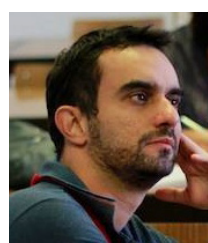

Muriel Emídio Pessoa do Amaral <muriealamaral@yahoo.com.br>

Doutorando em Comunicação pela Universidade Estadual Paulista (Unesp/Bauru). Bolsista pela Capes.

Programa de Pós-graduação em Comunicação

Universidade Estadual Paulista/Bauru

Av Eng Luiz Edmundo Carrijo Coube, 14-01 - Vargem Limpa

$17033-360$ - Bauru/SP 